\title{
EFFECTS OF BIOFERTILIZER CONTAINING MICROBIAL OF N-FIXER, P SOLUBILIZER AND PLANT GROWTH FACTOR PRODUCER ON CABBAGE (BRASSICA OLERACEAE VAR. CAPITATA) GROWTH AND SOIL ENZYMATIC ACTIVITIES: A GREENHOUSE TRIAL
}

\author{
Sarjiya Antonius and Dwi Agustiyani \\ Research Center for Biology-Indonesian Institute of Science \\ Jalan Raya Jakarta-Bogor Km 46 Cibinong 16911, Tel 021-8765066, Fax 8765062 \\ E-mail: sarjiya.antonius@lipi.go.id
}

\begin{abstract}
Biofertilizer has been identified as an alternative to chemical fertilizer to increase soil fertility and crop production in sustainable farming. The objective of this greenhouse study was to evaluate the effects of four different concentrations of biofertilizers containing Pseudomonas sp., Bacillus sp. and Streptomyces sp. on soil properties and to evaluate the growth of Brassica oleraceae var. capitata. The application treatments included control (no fertilizer) and four concentration of diluted biofertilizer per pot $(20 \mathrm{ml}, 40 \mathrm{ml}, 60 \mathrm{ml}$ and $80 \mathrm{ml}$ ). The application of biofertilizer containing beneficial bacteria significantly increased the growth of $\mathrm{B}$. oleraceae. The use of biofertilizer resulted higher biomass weight and length as well as root length. This greenhouse study also indicated that different amount of biofertilizer application had almost similar effects. Microbial inoculum not only increased plant harvest, but also improved soil properties, such as number of microorganisms, respiration and urease activities.
\end{abstract}

Key words: Bacillus sp, Brassica oleraceae, Greenhouse trial, PGPRs, Pseudomonas sp, and Streptomyces sp

\section{PENGANTAR}

Kubis (Brassica oleracea var. capitata) merupakan sayuran yang cukup bernilai ekonomi tinggi dan dalam budidayanya memerlukan perhatian yang lebih serius terutama berkaitan masalah pemupukan dan serangan hama. Fosfat dan nitrogen merupakan nutrisi esensial yang selama ini diandalkan untuk pertumbuhan kubis. Aplikasi pupuk anorganik $\mathrm{N}$ dan P dalam jumlah besar tidak hanya menyebabkan biaya produksi yang tinggi, tapi juga mencemari lingkungan (Yazdani dkk., 2009). Sebagian besar P dalam kondisi tidak terlarut, adalah tidak bisa dimanfaatkan oleh tanaman. Mikroba perakaran penambat $\mathrm{N}$, pelarut $\mathrm{P}$, penghasil hormon tumbuh, dan agen biokontrol mempunyai peran yang besar dalam membantu menyediakan nutrisi bagi tanaman sebagai mikroba penyubur perakaran dan menunjang pertumbuhan tanaman (Yang dkk., 2009). Lebih lanjut dikemukakan bahwa mikroba penyubur perakaran memberikan efek yang menguntungkan karena juga meningkatkankan ketahanan tanaman terhadap jamur patogen penyakit tanaman, bakteri, virus, dan nematoda.

Mikroba-mikroba tanah kandidat agen pupuk hayati bagian eksplorasi di kabupaten konservasi Malinau telah berhasil di seleksi secara kualitatif dengan ditumbuhkan pada media selektif. Dari uji lanjut tahap pendukung perkecambahan terbukti bahwa beberapa isolat tersebut dapat memacu perpanjang akar dan tumbuhnya tunas (Sarjiya dkk., 2009). Secara spesifik mikroba-mikroba hasil seleksi memiliki kemampuan dalam melarutkan P, menghasilkan hormone tumbuh Indole Acetic Acid (IAA) dan sebagai agen biokontrol. Isolat-solat mikroba tersebut berdasar indentifikasi 16S rDNA diketahui termasuk kelompok Bacillus, Pseudomonas dan Streptomyces (unpublished data).

Mikroba penyubur perakaran sangat penting guna mendukung pertumbuhan tanaman karena perannya mempengaruhi sifat biologi-kimia tanah, ketersedian nutrisi/hara dan pada akhirnya menentukan pertumbuhan dan hasil panen. Perbaikan sifat biokimia tanah dapat dilihat dari meningkatnya enzim-enzim tanah dan respirasi (Sarjiya dkk., 2007). Lebih lanjut dilaporkan bahwa pengkayaan pupuk organik (kompos) dengan mikroba penambat $\mathrm{N}$, Pelarut $\mathrm{P}$, dan agen biokontrol dapat meningkatkan produksi sayuran. Meskipun demikian, kajian aplikasi pupuk organic hayati cair yang mengandung mikroba penyuburan perakaran pada sayuran kobis (B. oletaceae) yang tumbuh didataran rendah masih jarang dilakukan. Untuk itu tujuan penelitian ini adalah mengkaji pengaruh beberapa dosis perlakuan pupuk organik hayati tehadap tanaman kobis pada kondisi rumah kaca. 


\section{BAHAN DAN CARA KERJA}

\section{Persiapan Starter dan Pembuatan Pupuk Organik Hayati}

Pra kultur mikroba dari Bacillus, Pseudomonas, dan Streptomyces ditumbuhkan pada $50 \mathrm{ml}$ media cair NB, yang diperkaya $\mathrm{Ca}\left(\mathrm{PO}_{4}\right)_{2}, \mathrm{NB}$ diperkaya dengan Tryptophan dan media YS yang diperkaya Tryptophan secara berturutan (Sarjiya dkk., 2009), dalam erlenmeyer volume $100 \mathrm{ml}$ dan di goyang dengan kecepatan 100 goyangan/menit selama 3 hari. Setiap hari diamati pertumbuhannya dengan mengukur derajat kekeruhan (optical density) menggunakan spektrofotometer.

Pupuk organik hayati dipersiapkan dengan bahanbahan meliputi gula merah ( $30 \mathrm{gr} / \mathrm{l})$, molase (30 gr/l), taoge $(60 \mathrm{~g} / \mathrm{l})$ tepung maizena $(2 \mathrm{~g} / \mathrm{l})$, agar-agar $(2 \mathrm{~g} / \mathrm{l})$, tepung ikan (10 g/l), tepung kedelai $(20 \mathrm{~g} / \mathrm{l})$ dan hara mikro: $\mathrm{Mg}$, $\mathrm{Mn}, \mathrm{Fe}, \mathrm{Cu}, \mathrm{Zn}$ (masing-masing: 0,001 g/l). Sebelum dicampurkan, tauge direbus dan diambil ekstraknya. Semua campuran bahan direbus, dan setelah dingin, maka pra kultur mikroba dicampurkan. Semua campuran bahan dan pra kultur mikroba dimasukkan ke dalam jerigen plastik yang sebelumnya telah dicuci bersih, dibilas dengan alkohol dan dengan akuades steril. Campuran bahan pupuk hayati dalam jirigen diberi aerasi dengan pompa udara (AQUASERENE SPA-602) selama 1 bulan.

\section{Percobaan Rumah Kaca}

Pot plastik ukuran 51 diisi tanah ( $2 \mathrm{~kg}$ ) yang sebelumnya telah diayak untuk memisahkan sisa tanaman dan batuan kerikil. Biji Kobis yang berkecambah (3 butir) ditanam dalam masing-masing pot, yang kemudian diseleksi dan dibiarkan satu tanaman tersisa yang homogen. Perlakuan 4 konstrasi pupuk organic hayati cair $(2,4,6$, dan $8 \mathrm{ml} /$ pot) diberikan sesuai rancangan percobaan acak lengkap dengan 5 ulangan. Setiap 2 miggu dilakukan pengamatan parameter pertumbuhan tanaman yaitu jumlah daun dan tinggi tanaman.

\section{Pengukuran Aktivitas Enzim Tanah dan Respirasi}

Sampel tanah sebanyak 300 gr diambil dari masingmasing pot ketika tanaman berumur 1,5 bulan. Sampel tanah tersebut langsung diukur aktivitas enzimnya, yaitu urease, fosfomoesterase dan respirasi di laboatorium dengan mengadopsi metode standar Schinner dkk. (1996).

\section{HASIL}

\section{Aktivitas Respirasi, Fosfomonoesterase, dan Urease}

Aktivitas respirasi, enzim fosfomonoestrase dan urease tanah secara umum menunjukkan tendensi lebih tinggi pada pot yang diberi perlakuan pupuk organik hayati dibanding pada tanaman kontrol. Meskipun terjadi peningkatan aktivitas respirasi pada tanaman yang diberi perlakuan, tetapi tingkat kenaikan aktivitas respirasi tidak linier sesuai kenaikan tingkat perlakuan yang diberikan, misalnya pada perlakuan $6 \mathrm{ml}$ dan $8 \mathrm{ml}$ per pot (Gambar 1).

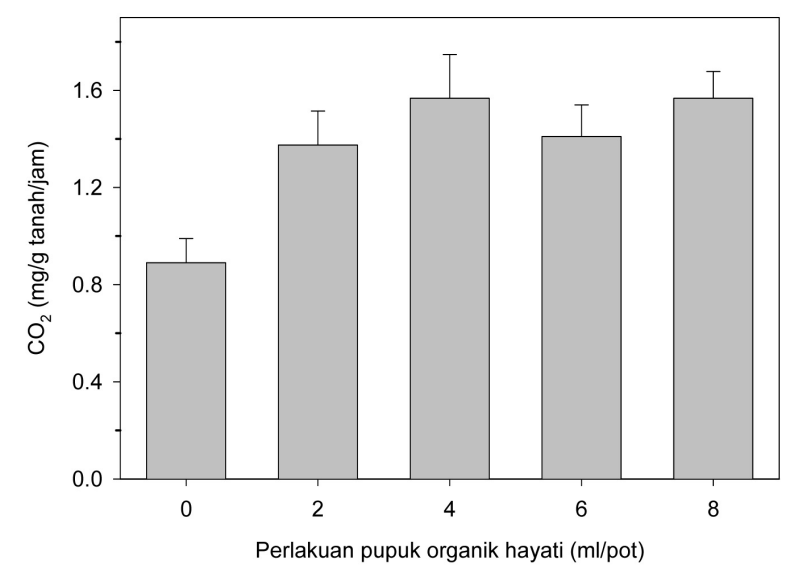

Gambar 1. Aktivitas respirasi tanah

Seperti halnya pada aktivitas enzim fosfomonoesterase (Gambar 2A), pada kontrol (tanpa perlakukan pupuk organic hayati) menunjukkan aktivitas terendah. Kenaikan aktivitas fosfomonoesterase juga tidak sebanding sesuai dengan kenaikan aplikasi pupuk organik hayati cair. Berbeda dengan aktivitas enzim urease (Gambar 2B) yang kenaikan aktivitasnya selaras dengan peningkatan dosis pemupukan pupuk organic hayati cair, dan pada dosis $60 \mathrm{ml} /$ pot merupakan aktivitas tertinggi dan pada $80 \mathrm{ml} /$ pot, tidak ada kenaikan aktivitas lagi. 


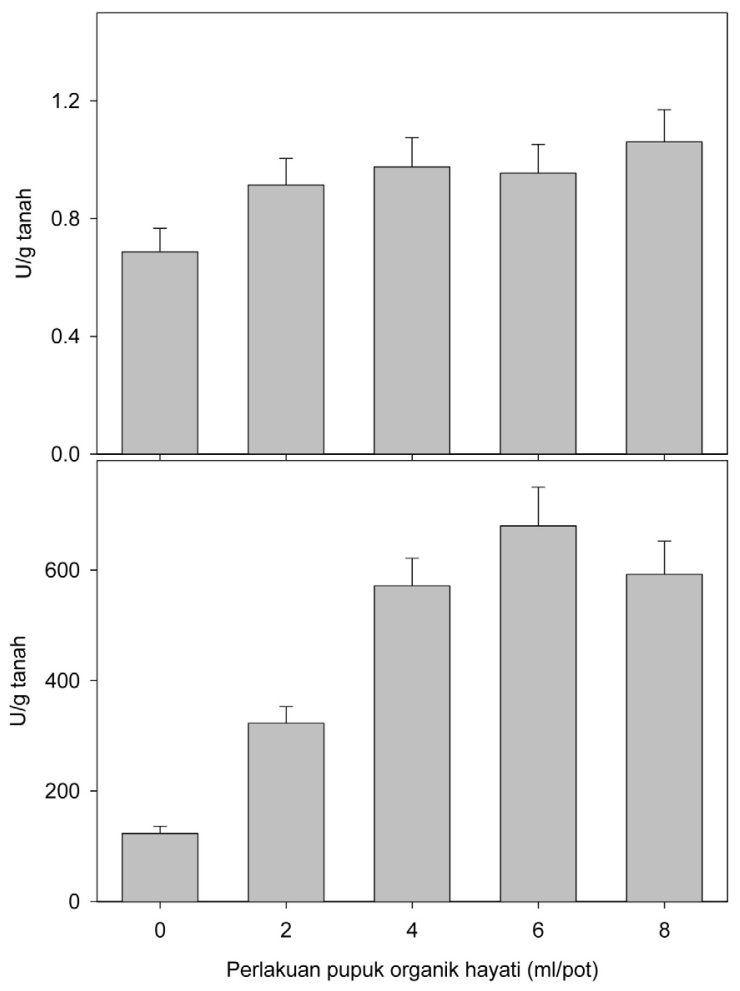

Gambar 2. Aktivitas enzim fosfomonoesterase dan urease

\section{Jumlah Daun, Tinggi Tanaman, Bobot Segar Kobis (Panen), Panjang dan Berat Akar}

Jumlah daun dan tinggi tanaman (Gambar 3) terendah didapatkan pada kontrol perlakuan, dan peningkatan jumlah daun maupun tinggi tanaman terlihat pada setiap perlakuan pupuk organik hayati meskipun peningkatan tersebut tidak paralel selaras dengan peningkatan dosis aplikasi.

Peningkatan bobot kobis (Gambar 3) pada waktu panen terlihat tidak selaras dengan masing-masing peningkatan dosis aplikasi pupuk organik hayati dan meskipun bobot tertinggi (320 gr) dicapai pada aplikasi $8 \mathrm{ml} /$ pot. Dibandingkan kontrol, peningkatan bobot panen mencapai $100 \%$. Peningkatan bobot panen tersebut selaras dengan peningkatan bobot akar dan panjang akar (Gambar 4) dengan ukuran sekitar $10 \mathrm{gr}$ dan $20 \mathrm{~cm}$ berturut-turut, atau setara dengan peningkatan sekita $30 \%$ dibandingkan kontrol.

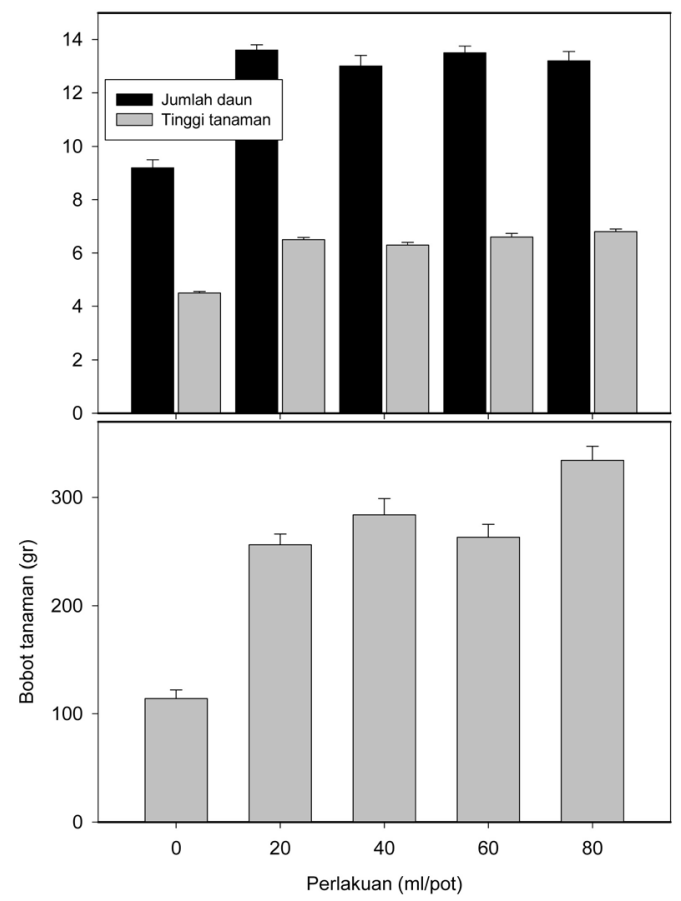

Gambar 3. Jumlah daun, tinggi tanaman dan bobot tanaman segar Kobis

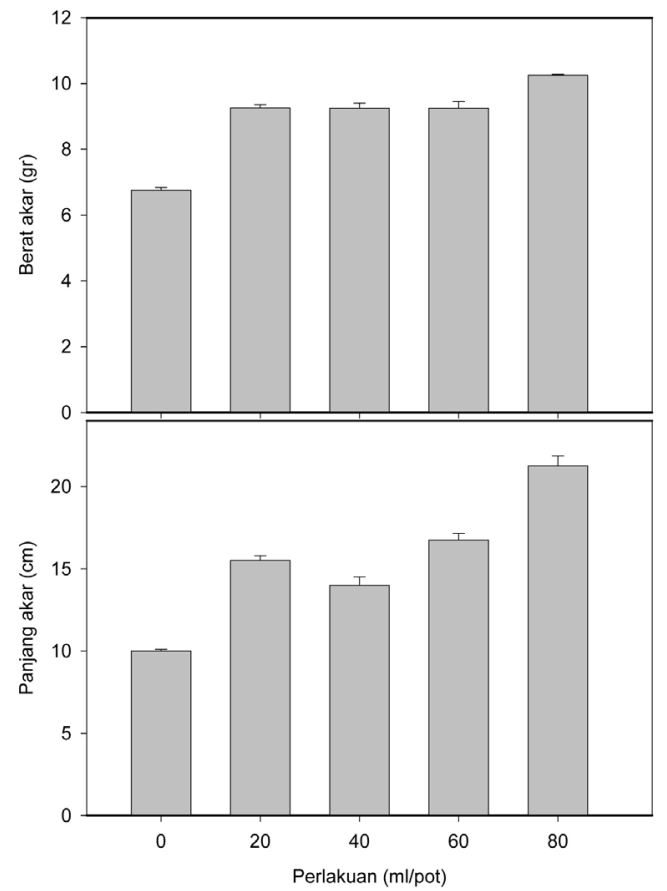

Gambar 4. Bobot akar dan panjang akar Kobis 


\section{PEMBAHASAN}

\section{Aktivitas Enzim Tanah}

Adanya peningkatan aktivitas enzim tanah yang meliputi respirasi, fosfomoestarase, dan urease pada aplikasi pupuk organik hayati cair jika dibandingkan kontrol (tanpa perlakuan) terlihat jelas pada percobaan tanaman kubis (B. oleraceae var. capitata) kondisi rumah kaca. Peningkatan aktivitas biologi tanah pada aplikasi pupuk organik yang diperkaya mikroba penyubur perakaran terhadap tanaman sayuran adalah konsisten seperti pada percobaan sebelumnya (Antonius dkk., 2007). Hal yang membedakan dengan percobaan-percobaan sebelumnya dan yang sudah umum dilakukan adalah bahwa mikroba penyubur perakaran tidak ditambahkan pada pupuk organik padat (kompos) melainkan justru ditumbuhkan pada media yang kaya akan sumber $\mathrm{C}, \mathrm{N}$, dan hara mikro. Setelah melalui proses inkubasi dengan sistem aerob penuh selama sekitar satu bulan, baru kemudian diaplikasikan. Pada kondisi demikian dimungkinkan mikroba-mikroba perakaran tersebut memperbanyak diri dan sekaligus menghasilkan senyawa-senyawa atau juga metabolit yang sangat berguna bagi tumbuhan dan juga dapat memperbaiki lingkungan tanah. Dilaporkan sebelumnya bahwa beberapa mikroba penyubur perakaran tersebut memiliki aktivitas ganda, seperti tidak hanya memiliki kemampuan melarutkan P tetapi juga mampu menghasilkan hormone tumbuh (Antonius dkk., 2009).

Peningkatan aktivitas biologi tanah untuk respirasi hampir sekitar $100 \%$ dan juga aktivitas urease mencapai hampir 300 persen menunjukkan bahwa ada peningkatan jumlah mikroba tanah sebagai dampak positif dari aplikasi pupuk organic hayati cair tersebut. Peningkatan populasi mikroba secara umum juga pernah dilaporkan pada aplikasi pupuk organik padat yang diperkaya mikroba penyubur perakaran pada suatu ekosistem tanah (Antonius dkk., 2007; Rahmansyah dkk., 2007; Hu and Cao, 2007). Sedangkan peningkatan aktivitas fosfomonoesterase tidak begitu signifikan, ini kemungkinan terkait dengan kondisi tanah yang netral sehingga tidak cukup tersedia $P$ terikat sebagai substrat enzim fosfomonoesterase.

\section{Parameter Agronomi Tanaman}

Akhir dari tujuan pemanfaatan pupuk organik hayati adalah terjadinya peningkatan produk hasil panen. Dalam penelitian ini karena basisnya adalah untuk pengembangan pertanian organik, maka dalam perlakuan tidak diberikan pupuk anorganik sebagai pembanding. Dalam percobaan ini sebagai pembanding adalah tanah yang mendapat perlakuan dasar pupuk kompos (20\%). Secara umum pemberian pupuk organik hayati dapat meningkatkan panjang akar (sekitar 100\%) maupun bobot akar tanaman kubis (sekitar $30 \%)$. Peningkatan yang signifikan terhadap parameter akar dimungkinkan dengan adanya peran hormon tumbuh (IAA) yang terkandung dalam pupuk organik hayati cair. Kolb dan Martin (1985) telah menunjukkan bahwa penyemprotan IAA pada dosis yang tepat dapat meningkatkan akar rambut, percabangan, dan panjang akar tanaman gandum. Laporan lainnya menyatakan bahwa aplikasi supernatan dari media pertumbuhan mikroba penghasil IAA dapat meningkat jumlah dan panjang aar tanaman kedelai (Molla dkk., 2001). Hal tersebut dapat memperkuat argumen pada penelitian ini sebagai dampak kandungan IAA. Telah dilaporkan bahwa pada screening awal, uji perkecambahan, dan uji kualitatif mikroba penyubur perakaran yang dipakai dalam penelitian ini mampu menghasilkan IAA (Antonius dkk., 2009).

Dengan adanya peningkatan panjang dan bobot akar pada percobaan aplikasi pupuk organik hayati cair berimplikasi pada kenaikan jumlah daun, tinggi tanaman, dan bobot panen kubis. Terkait dengan adanya kemampuan menghasilkan hormon tumbuh IAA, tidak menutup kemungkinan bahwa mikroba penyubur perakaran yang dipergunakan dapat menghasilkan hormon yang lain, misalkan cytokinin. Hormon ini sangat bermanfaat dalam mempengaruhi fisiologi tumbuhan khususnya dalam proses fotositesis, sehingga hasil akhir adalah meningkatkan hasil panen atau bobot biomas total pada tanaman kapas (Gossypium hirsutum) (Yong dkk., 2010). Penjelasan selanjutnya bahwa pupuk organic hayati cair yang diaplikasikan mengadung pula nutrisi lain, vitamin, unsur hara makro-mikro, dan juga protein. Perlu juga diingat pula bahwa tanaman dapat menyerap $\mathrm{N}$ dalam berbagai bentuk, termasuk protein (Paungfoo-Lonhienne dkk., 2008).

Sebagai kesimpulan bahwa pupuk organik hayati cair yang merupakan media penumbuhan mikroba penyubur perakaran dan otomatis mengandung agen mikrobanya sendiri dapat secara sinergi memberi efek pada berbaikan sifat biokimia tanah dan membantu menyediakan bahan penting guna mendukung pertumbuhan dan meningkatkan hasil panen.

\section{UCAPAN TERIMA KASIH}

Ucapan terima kasih penulis sampaikan kepada saudara Entis Sutisna, Koswara, saudari Nani Mulyani, dan Arie Rosmalina atas bantuannya dalam menyelesaikan penelitian ini. 


\section{KEPUSTAKAAN}

$\mathrm{Hu} \mathrm{C}$ and Cao Z, 2007. Size and activity of the soil microbial biomass and soil enzyme activity in long-term field Experiments. Word Joural of Agricultural Sciences 3: 63-70.

Kolb W and Martin P, 1985. Response of plant roots to inoculation with Azospirillum brasilense and to application of indole acetic acid dalam: Klingmüller W. (Ed.) Azospirillum III. Genetics, physiology, Ecology. Springer, Berlin Heidelberg, New York, pp. 215-221.

Molla AH, Shamsuddin ZH, and Saud HM, 2001. Mechanism of root growth and promotion of nodulation in vegetable soybean by Azospirillum brasilense. Commun. Soil Sci. Plant Anal., 32: 2177-2187.

Paungfoo-Lonhienne C, Lonhienne TGA, Rentsch, Robinson N, Christie M, Webb RL, Gamage HK, Carroll BJ, Schenk PM, and Schmidt S, 2008. Plants can use protein as a nitrogen source without assistance from other organisms. PNAS 115: 4524-4529.

Rahmansyah M, Antonius S, and Sulistinah N, 2009. Phosphatase and Urease Instability Caused by Pesticides Present In Soil Improved by Grounded Rice Straw. ARPN Journal of Agriculture and Biolgical Science 4(2): 56-62.

Sarjiya A, Laili N, Yanti, Nurkanto A, Agustyani D, 2009. Eksplorasi dan penapisan mikroba dari malinau sebagai agen hayati pendukung pertanian yang berkelanjutan. Proseding Lingkungan Hidup, Seminar Nasional Biologi XX dan Kongres PBI XIV UIN Maliki Malang, pp. 347-357.

Sarjiya A, Agustyani D, Rahmansyah M, and Martono B, 2007. Development of Sustainable agriculture: Soil Microorganisms Enzymantic Activity of Organic Farming on jabopuncur Catchment's Area Treated with agricultural wastes as Biofertilizier dalam Nugroho AP, Retnoaji B, Daryono BS, Maryani KD, Susandarini S, Marliana SM. Contribution Towards a Better Human Prosperity. Faculty of Biology-UGM, Jogyakarta, pp. 340-341.

Yang J, Kloepper JW, Ryu CM, 2009. Rhizosphere bacteria help plants tolerate abiotic stress. Trend in Plant Science 14: $1-4$.

Yazdani M, Bahmanyar MA, Pirdashti H, Esmaili MA, 2009. Effect of Phosphate Solubilization Microorganisms (PSM) and Plant Growth Promoting Rhizobacteria (PGPR) on Yield and Yield Components of Corn (Zea mays L.). World Academy of Science, Engineering and Technology 49: 90-93.

Yong JWH, Letham SB, Wong SC, Farquhar GD, 2010. Effects of root restriction on growth and associated cytokinin levels in cotton (Gossypium hirsutum) 37: 974-984.

Reviewer: Tim Reviewer 